\title{
АКТУАЛЬНІСТЬ ТА ОБҐРУНТОВАНІСТЬ НЕЙРОПСИХОЛОГІЧНОЇ ТА ФІЗІОТЕРАПЕВТИЧНОї РЕАБІЛІТАЦІї ХВОРИХ ІЗ ЗАКРИТОЮ ЧЕРЕПНО-МОЗКОВОЮ ТРАВМОЮ, ЗУМОВЛЕНОЮ ДІЄЮ ВИБУХОВОЇ ХВИЛІ
}

\author{
๑В. О. Коршняк, О. В. Коршняк \\ ДУ «Інститут неврології, психіатрії та наркології НАМН України», м. Харків
}

РЕЗЮМЕ. Пошкодження центральної нервової системи в учасників бойових дій на Сході України займають друге місце після кульових і осколкових поранень тулуба та кінцівок. Вибухові пошкодження за патогенезом та клініко-морфологічними проявами істотно відрізняються від звичайних механічних закритих черепно-мозкових травм. Цілком очевидно, що проблема віддалених наслідків, їх діагностики, адекватної клініко-патофізіологічної оцінки, лікування, реабілітації в цілому має важливе загальномедичне та соціально-економічне значення.

Мета - вивчення віддалених наслідків бойової черепно-мозкової травми для подальшої обґрунтованості вибору методів терапії та реабілітації.

Матеріал і методи. Обстежено 97 військових із даною нозологією. Патогенез ураження нервової системи при травматичній хворобі головного мозку зумовлений, головним чином, обмінними, токсичними, судинними і рефлекторними розладами. Зсув гомеостазу, як внутрішній стрес-чинник, запускає каскад патологічних механізмів.

Результати. Аналіз динаміки патологічного процесу показав, що не всі його ланки рівнозначні. Окремі ланки $\epsilon$ визначальними для подальшого розвитку патологічних процесів. У динаміці хвороби роль окремих ланок, навіть основного патологічного процесу, часто змінюється, а значить, і основна ланка не завжди $є$ постійною впродовж захворювання. На кожному з етапів розвитку хвороби можливі свої основні ланки патогенезу.

Висновки. Передбачаючи структурно-функціональні перебудови структур мозку, можна забезпечувати можливість керування процесами життєдіяльності. Апробовано й доведено результативність і ефективність нейропсихологічних та фізіотерапевтичних заходів реабілітації хворих.

КЛючовІ СлОВА: черепно-мозкова травма; віддалені наслідки черепно-мозкової травми; бойова травма; нейропсихологічна допомога; фізіореабілітаційні заходи; психотерапевтична допомога; вибухова хвиля.

Вступ. 3 кожним роком у нашій країні зростає частота закритих черепно-мозкових травм (ЗЧМТ), відповідно, збільшується кількість хворих із віддаленими наслідками (ВН) ЗЧМТ і зростає потреба вивчення цієї проблеми. Пошкодження центральної нервової системи (ЦНС) в учасників бойових дій на Сході України займає друге місце після кульових і осколкових поранень тулуба та кінцівок. Тільки за період з 2014 до 2018 рр. у неврологічний стаціонар Військово-медичного клінічного центру Північного регіону госпіталізовано понад 1300 військовослужбовців із ЗЧМТ $[4,14,16]$. За довгостроковими прогнозами, очікується подальше зростання частоти ЧМТ, а відповідно, і збільшення кількості хворих із віддаленими наслідками (за МKX-10 - Т 90.5). Однією із форм ЗЧМТ в період бойових дій є травма, зумовлена вибуховою хвилею від снаряда. Така травма - це складне комбіноване ушкодження, яке включає струс мозку, акустичні травми та вібротравми $[5,6,7]$. Вибухові пошкодження за патогенезом та клінікоморфологічними проявами істотно відрізняються від звичайних механічних ЗчМТ. Однією з провідних причин встановлення динамічного неврологічного і психіатричного спостереження в осіб 3 екзогенно-органічними захворюваннями головного мозку є психопатологічні наслідки ЧМТ. На- явність в анамнезі ЗЧМТ у різному проміжку часу по тому проявляється різноманіттям клінічних варіацій віддалених наслідків, що перебігають із частими станами декомпенсації, тимчасової непрацездатності, з подальшою інвалідизацією [3, 10, 13]. Цілком очевидно, що віддалені наслідки ЗчМТ, а саме: їх діагностика, адекватна клініко-патофізіологічна оцінка, лікування, реабілітація мають важливе загальномедичне та соціальноекономічне значення $[8,12]$.

Мета дослідження - вивчити особливості перебігу травматичного ураження мозку внаслідок вибухової ЗЧМТ, щоб розробити критерії діагностики, прогнозу зазначеної нозології, а також заходи нейропсихологічної та фізіотерапевтичної реабілітації у віддаленому періоді вибухової ЗЧМТ.

Матеріал і методи дослідження. Об'єКтом вивчення $\epsilon$ травматична хвороба головного мозку у віддаленому періоді вибухової ЗЧМТ. Предмет дослідження - клініко-параклінічні, біохімічні, нейропсихологічні показники хворих із травматичною хворобою головного мозку. Методи дослідження: клініко-неврологічні, психоневрологічні, біохімічні, електрофізіологічні, полісомнографічні, статистичні тощо.

Обстежено 97 хворих віком 23-37 років із зчМТ, спричиненою вибуховою хвилею в період 
Огляди літератури, оригінальні дослідження, погляд на проблему, ювілеї

перебування в зоні збройного конфлікту на Сході України, з давністю травми 1,5-3 роки. 3 анамнезу відомо, що відстань від місця вибуху снаряда чи міни до постраждалих становила від 4-5 до 1012 м. Усім хворим проводили клініко-неврологічне, психоневрологічне, біохімічне, електрофізіологічне, полісомнографічне обстеження та оцінювали стан їх вегетативної нервової системи (ВНC): визначали вегетативний тонус, вегетативну реактивність (ВР), вегетативне забезпечення діяльності (ВЗД). Одержані дані статистично обробляли за методом В. С. Генеса.

У дослідження включали постраждалих, які відповідали таким критеріям: а) вік 23-37 років; 6) відсутність соматичного і неврологічного обтяженого анамнезу; в) наявність лише легкої ЗЧМТ (без алкогольного сп'яніння, травм грудної клітки, туберкульозу та інших інфекційних захворювань в момент отримання травми). Дані критерії дозволили нам максимально виключити фактори, які 6 істотно впливали на перебіг хвороби.

Результати й обговорення. Клінічну характеристику віддаленого періоду було вивчено у 97 хворих, які перебували на стаціонарному лікуванні в неврологічному відділенні Військовомедичного клінічного центру Північного регіону (м. Харків) і в неврологічній клініці ДУ «ннститут неврології, психіатрії та наркології НАМН України» протягом 2014-2018 рр.

Відповідно до патофізіологічних наслідків віддаленої ЗЧМТ, основним напрямком у лікуванні було відновлення збалансованості дії відповідних функціональних систем головного мозку, що можливе тільки при комплексному медикаментозному та немедикаментозному лікуванні.

Патогенез ураження нервової системи при травматичній хворобі головного мозку змовлений, головним чином, обмінними, токсичними, судинними і рефлекторними розладами. Зсув гомеостазу, як внутрішній стрес-чинник, запускає каскад патологічних механізмів $[2,9]$. Церебральний гомеостаз - це стабільне функціонування мозку та окремих його систем у фізіологічних межах в період спокою і при дії різних стресорів. Синхронізуючі та десинхронізуючі системи $\epsilon$ складовою частиною лімбіко-ретикулярного комплексу, інтегративної системи, що здійснює надсегментарну вегетативну регуляцію $[1,8,15]$. У стані спокою відбувається зниження реактивності гіпоталамуса, а отже, й зниження емоційної збудливості, що приводить до зменшення низхідних кірково-гіпоталамо-соматичних розрядів у системі зворотного зв'язку. Особливості психоемоційних стресорів полягають у їх тенденції до хронізації та самопосилення. На відміну від гуморальних показників, їх точні значення не підда- ються чіткому підрахунку і вимірюванню, а використання суб'єктивних опитувальників виявляє значні варіації кінцевого значення показників. Психічним стресорам важче запобігти, ніж фізичним, вони можуть діяти навіть за відсутності подразника, що потребує іншого підходу в терапевтичних та реабілітаційних заходах. Для нормалізації психологічного стану хворих із ВН ЗчМТ використовували комплексний підхід, який поєднує методи психотерапії, рефлексотерапії, лікувальної фізкультури та фармакотерапії. Стратегія психотерапії була спрямована на усунення внутрішнього психологічного конфлікту, мобілізацію психічних можливостей пацієнта, зміну звичних «больових відчуттів», навчання пацієнтів методам саморегуляції больових відчуттів. Залежно від характеру психопатологічної симптоматики, вираження мотивацій та працездатності пацієнта для лікування можуть бути використані різні психотерапевтичні техніки - підтримавальна психотерапія, сугестивні методики (гіпноз, релаксація, медитація), когнітивно-біхевіоральна психотерапія, динамічна психотерапія, групова психотерапія, біологічний зворотний зв'язок.

Крім використання сучасних фармакологічних засобів, лікар має розпрацювати таку методологію, де головним $\epsilon$ не усунення всіх проявів патології, а регулювання ушкоджених ланок патогенезу, сприяння відновленню пристосувальнокомпенсаторних можливостей організму. Тобто, лікувальні заходи повинні бути спрямовані на забезпечення оптимального розвитку існуючих в організмі захисних реакцій, які сформувалися у процесі еволюції, мають свою структуру та динаміку розвитку.

Серед лікувальних терапевтичних заходів можна виокремити позитивний і обґрунтований вплив транскраніальної електроаналгезії (TKEA), краніоцеребральної гіпотермії (КЦГ), мікрохвильової резонансної терапії (МРТ), програмованої сенсорної депривації тощо. Проведені дослідження показали, що під впливом ТКЕА відновлюється функціонування вегетативної нервової системи, нормалізуються гуморальні та імунні показники, швидкість мозкового кровотоку, покращуються біоелектрична активність головного мозку, психологічний статус хворих, нормалізується температурний гомеостаз. Тобто, відзначено суттєвий вплив TKEA на регуляторні процеси, що приводять у більшості хворих до зникнення тих порушень, які були викликані черепно-мозковою травмою.

Після сеансу КЦГ поліпшився функціональний стан підкіркових структур: достовірно зменшилася частота сухожилкової анізорефлексії, атаксії, тремору пальців рук та повік, зникли або стали 
Огляди літератури, оригінальні дослідження, погляд на проблему, ювілеї

слабовираженими вегето-вісцеральні пароксизми. Нормалізувався артеріальний тиск майже у всіх обстежених (лише в одного пацієнта із 20 осіб зберігалася гіпертензія), причому це стосується випадків як гіпер-, так і гіпотензії. Майже повністю нормалізувався внутрішньочерепний тиск. Функціонування надсегментарних структур ВНС також нормалізувалося за даними коефіцієнта Хільдебранта, показників вегетативної реактивності та вегетативного забезпечення діяльності при проведенні орто-, кліностатичних проб. Разом з тим, у хворих після КЦГ нормалізувалися показники реоенцефалограми: реографічний індекс (PI), дикротичний індекс (ДКІ), діастолічний індекс (ДСІ), що свідчить про нормалізацію мозкового кровотоку. Наші дані дозволяють стверджувати, що краніоцеребральна гіпотермія, незважаючи на відсутність медикаментозного впливу, позитивно впливає на функціональний стан надсегментарних структур ВНС у хворих із віддаленими наслідками ЗЧМТ, що, вочевидь, відбувається за рахунок зовнішнього біокерування синхронізацією функціональної активності структур, які входять до кортико-гіпоталамічно-ретикулярної осі.

Курс МРТ викликає позитивну динаміку: це проявляється зменшенням або зникненням суб'єктивних проявів страждання, покращенням збалансованості відділів ВНС. Відзначено покращення температурної функції ВНС та когнітивних функцій ЦНС. В цілому можна спостерігати зменшення і (суттєве) дисрегуляційних, і дезадаптивних проявів у даної групи хворих. Метод програмованої сенсорної депривації позитивно вплинув на вегетативні порушення, що мають місце у хворих із ЧМТ, зумовленою дією вибухової хвилі $[6,7]$.

Результати наших досліджень показали високу позитивну ефективність сенсорної депривації при лікуванні астеноневротичних розладів хворих з бойовою ЗчМТ. Позитивна результативність методу сенсорної депривації, як ми вважаємо, зумовлена тим, що відбувається відновлення не тільки у психоемоційній сфері пацієнта, але й у збалансованості та синхронності в діяльності надсегментарних структур ВНС, адже зняття надлишкової сенсорної імпульсації зумовлює розділення діяльності функціональних систем мозку і їхню переналагоджуваність. Отже, сенсорна депривація забезпечує виконання одного з принципів програмованого біокерування.

Висновки. Результати експериментальних досліджень показали, що відновлення функцій ЦНС після ЧМТ відбувається із залученням особливих компенсаторних ресурсів нервової тканини - нейропластичності та нейрогенезу. Відповідно до сучасної концепції хвороби, яка базується на тривимірній моделі ВОО3 «хвороба - обмеження життєдіяльності - соціальна недостатність», обмеженням життєдіяльності хворого 3 наслідками ЗЧМТ є відсутність можливості брати участь у повсякденній діяльності в звичайному для здорової людини обсязі. Цей фактор є бар'єром для хворого і соціально дезадаптує його. Основними принципами реабілітації є: 1) комплексність лікувально-відновлювальних заходів; 2) етапність і послідовність лікування; 3) спрямований вплив на особистість хворого з урахуванням преморбідних особливостей. В основі реабілітації пацієнта з наслідками ЧМТ має бути індивідуальна програма, складена з урахуванням реабілітаційного потенціалу, що включає весь комплекс медичних і соціальних заходів і передбачає досягнення максимального рівня реабілітації - повної, часткової або побутової. Суть запропонованої технології полягає в тому, що за допомогою фізіотерапевтичних впливів - TKEA, КВЧ-терапії, КЦГ та/або програмованої сенсорної депривації - створюються умови для відновлення синхронної упорядкованої діяльності функціональних систем півкуль мозку, перш за все, надсегментарних утворів вегетативної нервової системи. Корекції дисрегуляційних порушень у структурах півкуль досягають за рахунок різноспрямованої дії вищезгаданих методик.

Отже, передбачаючи структурно-функціональні перебудови структур мозку, можна забезпечувати можливість керування процесами життєдіяльності.

Перспективи подальших досліджень. Своєчасність, адекватність надання спеціалізованої медичної допомоги значною мірою визначають стан постраждалих у поточний момент, особливості подальшого перебігу травматичного ушкодження мозку, ступінь вираження та тяжкість наслідків ЗЧМТ, інвалідизацію, зумовлену цими наслідками, рівень смертності. Своєрідність клінічної картини вибухової ЗЧМТ змушує шукати нові підходи до діагностики, лікування та реабілітації постраждалих на різних етапах захворювання. 3 огляду на це, актуальними є виявлення особливостей формування та перебігу травматичної хвороби мозку в постраждалих із вибуховою ЗЧМТ для розробки комплексу нових прогностичних критеріїв з метою оптимізації надання неврологічної, психотерапевтичної та фізіореабілітаційної допомоги. Дослідження віддалених наслідків бойової черепномозкової травми та поглиблене вивчення й обгрунтоване вдосконалення процесів нейропсихологічної та фізіотерапевтичної реабілітації значно покращує соціально-адаптаційні можливості цього контингенту хворих. 
Огляди літератури, оригінальні дослідження, погляд на проблему, ювілеї

\section{ЛІТЕРАТУРА}

1. Вегетативные расстройства / под ред. А. М. Вейна. - М. : МИА, 2003. - 752 с.

2. Живолупов С. А. Нейропластичность: патофизиологические аспекты и возможности терапевтической модуляции / С. А. Живолупов, И. Н. Самарцев // Журн. неврологии и психиатрии. - 2009. - № 4. - С. 78-85.

3. Кас Ю. В. Особливості закритої черепно-мозкової травми, зумовленої вибуховою хвилею, в учасників бойових дій на Сході України / Ю. В. Кас, В. О. Коршняк, В. Т. Поліщук // Вісник наукових досліджень. - 2015. № 2. - С. 41-44.

4. Коршняк В. О. Клініко-неврологічні особливості гострого періоду легкої черепно-мозкової травми внаслідок дії вибухової хвилі / В. О. Коршняк, Б. А. Насібуллін, Ю. В. Бовт // Укр. мед. часопис. - 2016. - № 3 (113). C. $122-123$.

5. Коршняк В. О. Сучасні погляди на механізм впливу вибухової хвилі на центральну нервову систему та формування неврологічної симптоматики / В. О. Коршняк, Б. А. Насібуллін // Міжнародний неврологічний журнал. - 2016. - № 6 (84). - С. 139-142.

6. Коршняк В. О. Вплив вибухової хвилі на формування неврологічної симптоматики у хворих з бойовою черепно-мозковою травмою / В. О. Коршняк // Міжнародний неврологічний журнал. -2016. - № 5 (83). - С. 83-87.

7. Коршняк В. О. Нейрофізіологічні механізми програмованої сенсорної депривації / В. О. Коршняк // Експериментальна і клінічна медицина. -2015. - № 4 (69). C. 94-99.

8. Лихтерман Л. Б. Сотрясение головного мозга / Л. Б. Лихтерман, А. Д. Кравчук, М. М. Филатова. - М., 2008. -160 c.

\section{REFERENCES}

1. Veyn, A.M. (Ed.). (2003). Vegetativnye rasstroystva [Vegetative disorders]. Moscow: MIA [in Russian].

2.Zhivolupov, S.A., \& Samartsev, I.N. (2009). Neyroplastichnost: patofiziologicheskie aspekty i vozmozhnosti terapevticheskoy modulyatsii [Neuroplasticity: pathophysiological aspects and possibilities of therapeutic modulation]. Zhurn. nevrologii i psikhiatrii - Journal of Neurology and Psychiatry, 4, 78-85 [in Russian].

3. Kas, Yu.V., Korshniak, V.O., \& Polishchuk, V.T. (2015). Osoblyvosti zakrytoi cherepno-mozkovoi travmy, zumovlenoi vybukhovoiu hvyleiu, v uchasnykiv boiovyh dii na skhodi Ukrainy [Features of closed craniocerebral trauma caused by an explosive wave in participants of combat operations in the east of Ukraine]. Visnyk naukovykh doslidzhen - Bulletin of Scientific Researches, 2, 41-44 [in Ukrainian].

4. Korshniak, V.O., Nasibullin, B.A., \& Bovt, Yu.V. (2016). Kliniko-nevrolohichni osoblyvosti hostroho periodu lehkoi cherepno-mozkovoi travmy vnaslidok dii vybuhovoi hvyli [Features of closed craniocerebral trauma caused by an explosive wave in participants of combat operations in the east of Ukraine]. Ukrainskyi medychnyi chasopys - Ukrainian Medical Journal, 3 (113), 122-123 [in Ukrainian].

5. Korshniak, V.O., \& Nasibullin, B.A. (2016). Suchasni pohliady na mekhanizm vplyvu vybukhovoi khvyli na tsen-
9. Клинико-неврологический, электрофизиологический и нейропсихологический аспект острого периода легкой закрытой черепно-мозговой травмы у комбатантов : 36. тез наук.-практ. конф. за участю міжнародних спеціалістів "Актуальні питання сучасної психіатрії, наркології та неврології" / В. И. Сухоруков, Ю. В. Бовт, Н. Н. Привалова, Л. П. Забродина. -Х., 2015. C. 283-286.

10. Шогам И. И. Экстралемнисковые расстройства чувствительности в клинической неврологии / И. И. Шогам. - К. : Здоров'я, 1988. - 158 с.

11. Blast exposure in rats with body shielding is characterized primarily by diffuse axonal injury / R. H. Garman, L. W. Jenkins, R. C. Switzer R. Bauman // J. Neurotrauma. 2011. - Vol. 28. - P. 947-959.

12. Ghajar J. Traumatic brain injury / J. Ghajar // Lancet. - 2000. - Vol. 356. - P. 923-929.

13. Chronic traumatic encephalopathy in blast-exposed military veterans and a blast neurotrauma / L. E. Goldstein, A. M. Fisher, C. A. Tagge [et al.] // Sci. Trans. Med. - 2012. - Vol. 4. - P. 134-160.

14. Korshnyak V. Clinikoneurological and neuropsychogical aspects of acute period of mild cranial brain trauma caused by shock wale / V. Korshnyak, V. Sukhorukov // "EUREKA: Health Sciences". - 2016. - Vol. 1. P. 14-18.

15. Luppino G. The organization of the frontal motor cortex / G. Luppino, G. Rizzolatti // News Physiol. Sci. 2000. - No. 15. - P. 951-955.

16. Blast-related traumatic brain injury / J. V. Rosenfeld, A. C. McFarlane, P. Bragge [et al.] // Article in the Lancet Neurology. - 2013. - Vol. 12. - P. 882-893.

tralnu nervovu systemu ta formuvannia nevrolohichnoi symptomatyky [Modern views on the mechanism of the impact of an explosive wave on the central nervous system and the formation of neurological symptoms]. Mizhnarodnyi nevrolohichnyi zhurnal - International Neurological Journal, 6 (84), 139-142 [in Ukrainian].

6. Korshniak, V.O. (2016). Vplyv vybukhovoi khvyli na formuvannia nevrolohichnoi symptomatyky u khvorykh z boiovoiu cherepno-mozkovoiu travmoiu [Influence of an explosive wave on the formation of neurological symptoms in patients with combat craniocerebral trauma]. Mizhnarodnyi nevrolohichnyi zhurnal - International Neurological Journal, 5 (83), 83-87 [in Ukrainian].

7. Korshniak, V.O. (2015). Neirofiziolohichni mekhanizmy prohramovanoi sensornoi depryvatsii [Neurophysiological mechanisms of programmable sensory deprivation]. Eksperymentalna i klinichna medytsyna - Experimental and Clinical Medicine, 4 (69), 94-99 [in Ukrainian].

8. Lihterman, L.B., Kravchuk, A.D., \& Filatova, M.M. (2008). Sotryaseniye golovnogo mozga [Concussion of the brain]. Moscow [in Russian].

9.Suhorukov, V.I., Bovt, Yu.V., Privalova, N.N., \& Zabrodina, L.P. (2015). Kliniko-nevrologicheskiy, elektrofiziologicheskiy i neyropsikhologicheskiy aspekt ostrogo perio- 
Огляди літератури, оригінальні дослідження, погляд на проблему, ювілеї

da legkoy zakrytoy cherepno-mozgovoy travmy u kombatantov [Clinical neurological, electrophysiological and neuropsychological aspects of the acute period of mild closed head injury in combatants]. Zb. tez nauk. prakt. conf: "Aktualni pytannia suchasnoi psikhiatrii, narkolohii ta nevrolohii" - Collection of theses of Scient. and Pract. Conference: "Actual Questions of Modern Psychiatry, Narcology and Neurology"(283-286). Kharkiv [in Russian].

10. Shogam, I.I. (1988). Ekstralemniskovye rasstroystva chuvstvitelnosti v klinicheskoy nevrologii [Extralemic sensitivity disorders in clinical neurologists]. Kyiv: Zdorovye [in Russian].

11. Garman, R.H., Jenkins, L.W., Switzer, R.C., \& Bauman, R. (2011). Blast exposure in rats with body shielding is characterized primarily by diffuse axonal injury. J. Neurotrauma, 28, 947-959.
12. Ghajar, J. (2000). Traumatic brain injury. Lancet, $356,923-929$.

13. Goldstein, L.E., Fisher, A.M., Tagge, C.A., Zhang, X.L., Velisek, L., Sullivan, J.A., ... \& McKee, A.C. (2012). Chronic traumatic encephalopathy in blast-exposed military veterans and a blast neurotrauma. Sci. Trans. Med., 4, 134-160.

14. Korshniak, V., \& Sukhorukov, V. (2016). Cliniconeurological and neuropsychogical aspects of acute period of mild cranial brain trauma caused by shock wale. "EUREKA: Health Sciences", 1, 14-18.

15. Luppino, G., \& Rizzolatti, G. (2000). The organization of the frontal motor cortex. News Physiol. Sci., 15, 951-955.

16. Rosenfeld, J.V., McFarlane, A.C., Bragge, P., Armonda, R.A., Grimes, J.B., \& Ling, G.S. (2013). Blast-related traumatic brain injury. Article in the Lancet Neurology, 12, 882-893.

\title{
АКТУАЛЬНОСТЬ И ОБОСНОВАННОСТЬ НЕЙРОПСИХОЛОГИЧЕСКОЙ И ФИЗИОТЕРАПЕВТИЧЕСКОЙ РЕАБИЛИТАЦИИ БОЛЬНЫХ С ЗАКРЫТОЙ ЧЕРЕПНО-МОЗГОВОЙ ТРАВМОЙ, ОБУСЛОВЛЕННОЙ ДЕЙСТВИЕМ ВЗРЫВНОЙ ВОЛНЫ
}

○В. А. Коршняк, Е. В. Коршняк

\author{
ГУ «Институт неврологии, психиатрии и наркологи НАМН Украины», г. Харьков
}

РЕЗЮМЕ. Повреждения центральной нервной системы у участников боевых действий на Востоке Украины занимают второе место после пулевых и осколочных ранений туловища и конечностей. Повреждения, вызванные взрывной волной, по патогенезу и клинико-морфологическим проявлениям существенно отличаются от обычных механических закрытых черепно-мозговых травм. Совершенно очевидно, что проблема отдаленных последствий, их диагностики, адекватной клинико-патофизиологической оценки, лечения, реабилитации в целом имеет важное общемедицинское и социально-экономическое значение.

Цель - изучение отдаленных последствий боевой черепно-мозговой травмы для дальнейшей обоснованности выбора методов терапии и реабилитации.

Материал и методы. Обследовано 97 военных по данной нозологии. Патогенез поражения нервной системы при травматической болезни головного мозга обусловлен, главным образом, обменными, токсичными, сосудистыми и рефлекторными расстройствами. Сдвиг гомеостаза, как внутренний стресс-фактор, запускает каскад патологических механизмов.

Результаты. Анализ динамики патологического процесса показал, что не все его звенья равнозначны. Отдельные звенья являются определяющими для дальнейшего развития патологических процессов. В динамике болезни роль отдельных звеньев, даже основного патологического процесса, часто меняется, а значит, и основное звено не всегда является постоянным на протяжении болезни. На каждом из этапов развития болезни возможны свои основные звенья патогенеза.

Выводы. Предвидя структурно-функциональные перестройки структур мозга, можно обеспечивать возможность управления процессами жизнедеятельности. Апробирована и доказана результативность и эффективность нейропсихологических и физиотерапевтических мероприятий реабилитации больных.

КЛЮЧЕВЫЕ СЛОВА: черепно-мозговая травма; отдаленные последствия черепно-мозговой травмы; боевая травма; нейропсихологическая помощь; физиореабилитационные мероприятия; психотерапевтическая помощь; взрывная волна.

\section{ACTUALITY AND FOUNDATION OF NEUROPSYCHOLOGICAL AND PHYSIOTHERAPEUTIC REHABILITATION IN PATIENTS WITH CLOSED TRAUMATIC BRAIN INJURY CAUSED BY ACTION OF THE EXPLOSIVE WAVE}

\author{
○V. O. Korshniak, O. V. Korshniak \\ Institute of Neurology, Psychiatry and Narcology of the NAMS of Ukraine, Kharkiv
}

SUMMARY. Damage to the central nervous system among participants in military operations in the east of Ukraine ranks second after bullet and fragmentation wounds to the trunk and extremities. Damages caused by the blast wave, according to pathogenesis and clinical and morphological manifestations, differ significantly from the usual mechanical closed craniocerebral injuries. 
Огляди літератури, оригінальні дослідження, погляд на проблему, ювілеї

It is quite obvious that this problem of remote consequences, , their diagnosis, adequate clinico-pathophysiological evaluation, treatment, rehabilitation in general, have an important general medical and socio-economic significance.

The aim - to study the long-term consequences of a military brain injury for the further validity of the choice of therapy and rehabilitation methods.

Material and Methods. There were examined 97 military men with this nosology. The pathogenesis of damage to the nervous system in traumatic brain disease is mainly due to metabolic, toxic, vascular and reflex disorders. The shift of homeostasis, as an internal stress factor, triggers a cascade of pathological mechanisms.

Results and Discussion. An analysis of the dynamics of pathological processes showed that not all of its links are equivalent. Individual links of pathogenesis are crucial for the further development of pathological processes. In the dynamics of the disease, the role of individual links, even the main pathological process, often changes, and so the main link is not always constant throughout the illness. At each stage of the development of the disease, its main their own links in pathogenesis are possible.

Conclusions. Anticipating the structural and functional rearrangements of the structure of the brain, it is possible to provide the possibility of controlling vital processes. The efficacy and effectiveness of neuropsychological and physiotherapeutic measures of rehabilitation of patients were tested and proved.

KEY WORDS: traumatic brain injury; distant consequences of traumatic brain injury; military traumatic brain injury; neuropsychological assistance; physiotherapy measures; psychotherapeutic assistance; explosive wave.

Отримано 12.02.2019 